\title{
Boron Supplementation in Broiler Diets
}

Author(s)

Fassani EJ1

Bertechini $A G^{2}$

Brito $\mathrm{JAG}^{3}$

Kato $\mathrm{RK}^{4}$

Fialho $\mathrm{ET}^{2}$

Geraldo $A^{4}$

Professor - Faculdade Ciências Agrárias UNIFENAS - Alfenas, MG, Brazil

2 Professor - Departamento de Zootecnia UFLA/CNPq - Lavras, MG, Brazil

3 Student - Departamento de Zootecnia UFLA/CNPq - Lavras, MG, Brazil

4 Ph.D. Student - Departamento de Zootecnia - UFLA/CAPES - Lavras, MG, Brazil

\section{Mail Address}

Édison José Fassani

Rua Santana, 08

CP 65

37.200-000 - Lavras, MG, Brazil

E-mail: fassani@bol.com.br

\section{Keywords}

animal nutrition, boron, broiler, chicken, performance.

\section{ABSTRACT}

Boron supplementation in broiler feed is not a routine practice. However, some reports suggest a positive effect of boron on performance. This study assessed the effects of boron supplementation on broiler performance. Diets were based on maize and soybean meal, using boric acid P.A. as boron source. Six supplementation levels $(0,30$, $60,90,120$ and 150 ppm) were evaluated using 1,440 one-day old males housed at a density of 30 chickens in each of 48 experimental plots of $3 \mathrm{~m}^{2}$. A completely randomized block design was used with 8 replicates. Feed intake, weight gain and feed conversion were assessed in the periods from 1 to 7 days, 1 to 21 days and 1 to 42 days of age, and viability was evaluated for the total 42-day rearing period. No performance variable was affected by boron supplementation ( $p>0.05$ ) in the period from 1 to 7 days. The regression analysis indicated an ideal level of $37.4 \mathrm{ppm}$ of boron for weight gain from 1 to 21 days $(p<0.05)$ without affecting feed conversion $(p>0.05)$, although feed intake was reduced linearly with increased boron levels $(p<0.05)$. In the total rearing period ( 1 to 42 days), the level of $57 \mathrm{ppm}$ boron was adequate for weight gain $(p<0.01)$ without affecting feed conversion ( $p>0.05)$. Ash and calcium percentages in the tibias of broilers and viability in the total rearing period were not affected by boron supplementation ( $p>0.05)$.

\section{INTRODUCTION}

Brazilian poultry industry became competitive and specialized in recent decades and has currently an outstanding position in the world. The key to such success was mainly the improvement in management, health conditions, nutrition research, and genetics that resulted in the modern commercial lines of broilers.

However, many questions still have to be answered in all segments of the poultry industry. In the field of animal nutrition, the role of some trace minerals is not completely elucidated and contradictory results are reported in the literature. In this context, some studies after the late $80 s^{\prime}$ focused on the micro-element boron, which is considered essential for superior plants but not for men or animals (Underwood \& Suttle, 1999). A few studies are described in the international literature, but there is no concrete definition of the real function of boron and its possible requirements for poultry (broilers, laying hens and breeders).

Some functions and relationships of boron were suggested by Hunt and Nielsen (1981), including improvement of the growth rate, nutritional efficiency, calcium and phosphorus retention in broilers, besides reduction of vitamin D deficiency symptoms. Some studies also suggested that boron plays an important role in the metabolism of macro-minerals in broilers, mainly calcium, improving the balance of this mineral and 
Fassani EJ, Bertechini AG, Brito JAG, Kato RK, Fialho ET, Geraldo A
Boron Supplementation in Broiler Diets bone strength, and reducing losses due to bone fractures, mainly in processing plants (Elliot \& Edwards, 1992; Rossi et al., 1993).

Although boron is not considered essential for poultry or most animals, the inclusion of $2 \mathrm{ppm}$ in poultry feed was recommended by NRC (1984), no matter which poultry category or type of production. Such suggestions are not present in the requirements for poultry in 1994 (NRC, 1994). Therefore, the only available recommendations are from experimental and purified diets.

Rossi et al. (1990) reported the effects of four boron levels $(0,20,80$ and 320 ppm) combined with two levels of riboflavin (4.4 and $17.6 \mathrm{ppm}$ ) in the diets of broiler chickens from 1 to 49 days. At 21 days of age, feed intake, body weight and mortality were significantly lower for broilers given 320 ppm boron in the diet. Besides, broilers fed diets containing boron had better feed conversion in the experimental period when compared to the control group (0 ppm boron). The three tested boron levels had no effect on tibia weight and ash content. The highest level of riboflavin in the diets did not compensate for the adverse effects of the highest boron level on body weight. However, lower boron levels combined with riboflavin resulted in a significant improvement in broiler body weight at the end of the experimental period.

Elliot \& Edwards (1992) evaluated different levels of boron supplementation in the diet $(0,5,10$ and 20 ppm), as well as the possible interaction between boron, calcium (0.65 and $0.90 \%)$ and cholecalciferol (110 and 1,100 ICU). Boron did not affect weight gain, feed efficiency or the incidence of tibial dyschondroplasia, but had a quadratic effect on bone ash (decreased ash \% starting from $10 \mathrm{ppm}$ ). There were no interactions among the evaluated variables.

Boron requirements for broiler chickens in the first 21 days of age were evaluated in two trials with different supplementation levels: 0, 5, 40, 80 and 120 ppm in the first experiment and 0,60,120, 240 and 360 ppm in the second experiment (Rossi et al., 1993). Supplementation with $5 \mathrm{ppm}$ boron resulted in a positive response; broilers were heavier and had more resistantance to tibia breaking strength. On the other hand, broilers fed higher concentration of boron (360 $\mathrm{ppm}$ ) in the second trial were lighter than those broilers given non-supplemented diet. Neither boron levels in the liver nor broiler development were affected by diets containing more than 240 ppm boron. The authors concluded that the results were not definitive or indicative of a boron requirement in broiler diets based on maize and soybean meal.
Wilson \& Ruszler (1997) studied the effects of boron supplementation in broiler diets and suggested that the addition of $50 \mathrm{ppm}$ boron improved some bone characteristics (resistance to breaking, shear force and ash percentage) but did not influence weight gain. Goihl (2002) reported that low levels of boron added to pig diets ( 5 and $10 \mathrm{ppm}$ ) were beneficial, resulting in improved weight gain, nutritional efficiency, and calcium and phosphorus retention. Although the results were indicative of a possible function of boron in pigs, it was suggested that the ideal supplementation levels should be determined based on additional studies (Goihl, 2002).

The objective of the present study was to determine the effects of boron diet supplementation on the performance and bone characteristics of broilers.

\section{MATERIAL AND METHODS}

The trial was carried out at the Department of Animal Science of Federal University of Lavras, MG, Brazil. A total of 1,440 one-day-old male chicks of the broiler strain AG-Ross 508 were used. The broilers were distributed in a completely randomized block design with 6 treatments (boron levels) and 8 replicates per treatment, and experimental units were $3 \mathrm{~m}^{2}$-pens with 30 chickens per pen.

Treatments consisted of mash diets based on maize and soybean meal and supplemented with boron levels of $0,30,60,90,120$ and 150 ppm. Boric acid P.A. (17.5\% boron) was used as the boron source to prepare a boron premix containing $150 \mathrm{ppm}$ boron (857.63 g boric acid $+142.37 \mathrm{~g}$ kaolin). This first premix was combined with inert at different proportions to determine the different levels of boron in the premixes that were added to the diets at $0.1 \%$ level, as shown in Table 1. The broilers were fed four diets during the rearing period ( 1 to 7,8 to 21,22 to 33 and 34 to 42 days of age) (Table 2) following the recommendations of Rostagno et al. (2000).

Broilers were given water and feed ad libitum throughout the experiment. Feed intake and weight gain were measured at 7,21 , and 42 days of age, and feed conversion was calculated. The maximum and minimum temperatures inside the poultry house and broiler mortality were recorded daily.

At the end of the experiment, one broiler per experimental unit was slaughtered and the left tibia was sampled for analysis of ash, calcium and phosphorus percentages following the methodologies described by Silva (1998). 
Fassani EJ, Bertechini AG, Brito JAG, Kato RK, Fialho ET,

\section{Geraldo A}

Table 1 - Composition of boron premixes added to the diets.

\begin{tabular}{lrrrrrrr} 
Ingredients & \multicolumn{6}{c}{ Boron Level, } \\
\cline { 2 - 7 } & $\mathbf{0}$ & $\mathbf{3 0}$ & $\mathbf{6 0}$ & $\mathbf{9 0}$ & $\mathbf{1 2 0}$ & $\mathbf{1 5 0 *}$ \\
Boron premix & 150ppm, kg & 0 & 0.020 & 0.040 & 0.060 & 0.080 & 0.100 \\
Kaolin, kg & 0.100 & 0.080 & 0.060 & 0.040 & 0.020 & 0 \\
Total, kg. & 0.100 & 0.100 & 0.100 & 0.100 & 0.100 & 0.100 \\
\hline
\end{tabular}

Total, $\mathrm{kg}$.

$\begin{array}{llllll}0.100 & 0.100 & 0.100 & 0.100 & 0.100 & 0.100\end{array}$

* Levels per kilogram: $857.63 \mathrm{~g}$ boric acid $+142.37 \mathrm{~g}$ kaolin.

Data were submitted to analysis of variance and significant results were submitted to polynomial regression analysis using the Sisvar Software (Ferreira, 1999).

\section{RESULTS AND DISCUSSION}

The effects of boron supplementation on broiler performance are shown in Table 3. Feed intake, weight gain and feed conversion at 7 days of age were not affected by boron supplementation ( $p>0.05$ ). However, in the period from 1 to 21 days of age, weight gain was influenced by a quadratic increase $(p<0.05)$ that indicated best weight gain with 37.4 ppm of supplemented boron. This result contradicts results presented by Elliot \& Edwards (1992), who reported no effects of boron supplementation up to $20 \mathrm{ppm}$ in broiler diets. Nevertheless, Rossi et al. (1993) detected a positive response in weight gain with the supplementation of $5 \mathrm{ppm}$ boron to broilers from 1 to 21 days of age. Feed intake in the period from 1 to 21 days of age was affected linearly $(p<0.05)$ and reduced as the boron level increased in the diets. However, feed conversion in the same period did not reflect the lower feed intake $(p>0.05)$. A quadratic effect was also found $(p<0.05)$ for weight gain when the whole rearing period was considered ( 1 to 42 days of age). The derivation of the equation indicated that $57 \mathrm{ppm}$ boron was the most effective level of supplementation for weight gain in the period from 1 to 42 days, a level that is higher than the level suggested for the period from 1 to 21 days (37.4 ppm).

Rossi et al. (1990) also reported that the supplementation of boron and riboflavin resulted in a positive effect on weight gain in the period from 1 to 49 days at supplementation levels of 20 to $80 \mathrm{ppm}$ boron when compared to the control group. Feed intake in the period 1 to 42 days of age presented a cubic response surface $(p<0.05)$, and this did not allow to make inferences on this variable. Feed conversion from 1 to 42 days as well as feed conversion from 1 to

Table 2 - Percentage composition of experimental diets.

\begin{tabular}{|c|c|c|c|c|}
\hline \multirow[t]{2}{*}{ Ingredients } & \multicolumn{4}{|c|}{ Phase (age) } \\
\hline & 1 to 7 days & 8 to 21 days & 22 to33 days & 34 to 42 days \\
\hline Corn & 56.565 & 59.213 & 61.919 & 65.785 \\
\hline Soybean meal & 37.188 & 34.404 & 31.287 & 27.988 \\
\hline Dicalcium phosphate & 1.892 & 1.774 & 1.638 & 1.439 \\
\hline Limestone & 0.997 & 0.966 & 0.933 & 0.942 \\
\hline Salt & 0.457 & 0.440 & 0.411 & 0.386 \\
\hline Soybean oil & 2.118 & 2.352 & 2.982 & 2.643 \\
\hline Vitamin premix ${ }^{1}$ & 0.100 & 0.100 & 0.100 & 0.100 \\
\hline Mineral premix ${ }^{2}$ & 0.100 & 0.100 & 0.100 & 0.100 \\
\hline DL-Methionine & 0.161 & 0.225 & 0.203 & 0.178 \\
\hline L-Lysine $\mathrm{HCL}$ & 0.167 & 0.170 & 0.174 & 0.184 \\
\hline Choline Chloride, $70 \%$ & 0.080 & 0.080 & 0.080 & 0.080 \\
\hline Zn Bacitracin & 0.025 & 0.025 & 0.025 & 0.025 \\
\hline Anticoccidian ${ }^{3}$ & 0.050 & 0.050 & 0.050 & 0.050 \\
\hline Boron Premix ${ }^{4}$ & 0.100 & 0.100 & 0.100 & 0.100 \\
\hline TOTAL, kg. & 100 & 100 & 100 & 100 \\
\hline \multicolumn{5}{|c|}{ Calculated Composition } \\
\hline Metabolizable Energy, kcal/kg & 2,950 & 3,000 & 3,075 & 3,100 \\
\hline Crude Protein, \% & 21.92 & 20.88 & 19.69 & 18.53 \\
\hline Calcium, \% & 0.988 & 0.939 & 0.883 & 0.828 \\
\hline Available Phosphorus, \% & 0.466 & 0.441 & 0.412 & 0.372 \\
\hline Methionine + Cystine, \% & 0.926 & 0.879 & 0.827 & 0.775 \\
\hline Lysine, \% & 1.307 & 1.239 & 1.162 & 1.088 \\
\hline Sodium, \% & 0.224 & 0.216 & 0.203 & 0.192 \\
\hline
\end{tabular}




\begin{tabular}{|c|c|c|c|c|c|c|c|}
\hline \multirow[t]{2}{*}{ Variables } & \multicolumn{6}{|c|}{ Boron Level, ppm } & \multirow[t]{2}{*}{ CV, \% } \\
\hline & 0 & 30 & 60 & 90 & 120 & 150 & \\
\hline Feed Intake 1 - 7 days (g) & 150.4 & 156.6 & 155.2 & 156.0 & 154.0 & 152.6 & 3.4 \\
\hline Feed Intake 1 - 21 days (g) & 1159.5 & 1171.4 & 1145.3 & 1138.4 & 1108.9 & 1093.7 & 3.3 \\
\hline Feed Intake $1-42$ days $^{2}(\mathrm{~g})$ & 4683.0 & 4543.4 & 4554.6 & 4582.1 & 4511.9 & 4370.7 & 3.2 \\
\hline Body weight gain 1 - 7 days (g) & 129.9 & 132.8 & 131.8 & 131.2 & 130.2 & 129.4 & 5.8 \\
\hline Body weight gain $1-21$ days $^{3}(\mathrm{~g})$ & 784.6 & 798.5 & 794.1 & 775.1 & 762.2 & 734.7 & 5.0 \\
\hline Body weight gain 1 - 42 days $(\mathrm{g})$ & 2559.3 & 2535.3 & 2627.9 & 2573.9 & 2523.1 & 2477.2 & 2.3 \\
\hline Feed Conversion 1 - 7 days (kg/kg) & 1.16 & 1.18 & 1.18 & 1.20 & 1.18 & 1.19 & 5.5 \\
\hline Feed Conversion 1 - 21 days $(\mathrm{kg} / \mathrm{kg})$ & 1.48 & 1.47 & 1.44 & 1.47 & 1.46 & 1.49 & 3.5 \\
\hline Feed Conversion 1 - 42 days $(\mathrm{kg} / \mathrm{kg})$ & 1.83 & 1.79 & 1.73 & 1.78 & 1.79 & 1.77 & 3.2 \\
\hline Viability at 42 days of age, \% & 96.7 & 98.3 & 96.7 & 97.0 & 97.4 & 97.0 & 3.2 \\
\hline
\end{tabular}

21 days was not significantly affected ( $p>0.05)$ by boron supplementation in the diets. This was due to the lower weight gain and feed intake in birds supplemented with the highest levels of boron in the evaluated periods. Rearing viability was evaluated for the period from 1 to 42 days and was not affected ( $p>0.05)$ by boron supplementation. Most of the mortality was due to sudden death.

Bone ash and calcium levels in the tibias at 42 days of age were expressed as percentages on a de-fatted dry matter basis and were not significantly affected ( $p>0.05$ ) by boron supplementation (Table 4). Similarly, Rossi et al. (1990) reported no effect of boron supplementation on bone ash, even when boron levels up to 320 ppm were used. However, Elliot \& Edwards (1992) reported a quadratic effect of boron on bone ash, so that ash percentage was lower in broilers fed with $10 \mathrm{ppm}$ or higher levels of boron. Contrary results were presented by Wilson \& Ruzler (1997) who suggested that $50 \mathrm{ppm}$ boron in broiler diets improved some bone characteristics, including ash percentage. The results reported here and results previously reported (Rossi etal., 1990; Elliot \& Edwards, 1992; Wilson \& Ruzler, 1997) show different effects of boron on bone characteristics. Furthermore, other micronutrients present in the feed might also interact with boron and affect the results. The genetic influence on performance cannot be overlooked when boron is supplemented in the feed.

\section{CONCLUSIONS}

Broiler diets based on maize and soybean meal should be supplemented with 37.4 ppm boron in theperiod from 1 to 21 days of age as it improves
Table 4 - Effect of boron supplementation on bone ash and calcium levels in broiler tibias at 42 days of age, expressed as percentage of the de-fatted dry matter.

\begin{tabular}{lccccccc} 
Variables & \multicolumn{8}{c}{ Boron Level $(\mathbf{p p m})$} & \multirow{2}{*}{ CV, \% } \\
\cline { 2 - 7 } & $\mathbf{0}$ & $\mathbf{3 0}$ & $\mathbf{6 0}$ & $\mathbf{9 0}$ & $\mathbf{1 2 0}$ & $\mathbf{1 5 0}$ & \\
& & & & & & & \\
Ash, \% & 58.49 & 57.63 & 56.96 & 58.06 & 58.22 & 58.15 & 2.0 \\
Calcium, \% & 20.97 & 20.79 & 20.17 & 20.65 & 20.72 & 20.74 & 2.7 \\
\hline p $>0.05$. & & & & & & &
\end{tabular}

weight gain. However, when a single mineral premix is used throughout the rearing phase, supplementation should be increased to $57 \mathrm{ppm}$ boron. Studies should be carried out at the final rearing phase to confirm possible differences in the boron effects on broilers after 21 days of age.

\section{REFERENCES}

Elliot MA, Edwards $\mathrm{H}$. Studies to determine whether an interaction exists among boron, calcium, and cholecalciferol on the skeletal development of broiler chickens. Poultry Science 1992; 71:677690.

Ferreira DF. Sistema para análise de variância para dados balanceados (SISVAR). Lavras (MG): UFLA; 1999. 92p.

Goihl J. More research needed on boron supplementation of swine diets. Feedstuffs 2002; 74(4):10 and 27.

Hunt CD, Nielsen FH. Interaction between boron and cholecalciferol in the chick. In: McHowell J, Gawthorne JH, White CL, editors. Trace element metabolism in man and animals 4. Canberra: Australian Academy of Science; 1981. 597-600.

NRC. National Research Council. Nutrients requirements of poultry. $8^{\text {th }}$ ed. Washington, D.C.:National Academic Press; 1984. 71p. 
Fassani EJ, Bertechini AG, Brito JAG, Kato RK, Fialho ET, Geraldo A

NRC. National Research Council. Nutrients requirements of poultry. $9^{\text {th }}$ ed. Washington, D.C.:National Academic Press; 1994. 155p.

Rossi AF, Bootwalla SM, Miles RD. Boron and riboflavin addition to broiler diets. Poultry Science 1990:69 suppl.1:186.

Rossi AF, Miles RD, Damron BL, Flunker LK. Effects of dietary boron supplementation on broilers. Poultry Science 1993; 72:2124-2130.

Rostagno HS, Albino LFT, Donzele JL, Gomes PC, Ferreira AS, Oliveira RF, Lopes DC. Tabelas brasileiras para aves e suínos (Composição de alimentos e exigências nutricionais). Viçosa (MG):UFV, Imprensa Universitária; 2000. 141p.

Silva DJ. Análise de alimentos: Métodos químicos e biológicos. Viçosa (MG): UFV; 1998. 166p.

Underwood EJ, Suttle NF. The mineral nutrition of livestock. $3^{\text {rd }}$ ed. London: CABI Publishing; 1999. 602p.

Wilson JH, Ruszler PL. Effects of boron on growing pullets. Biological Trace Elements Research 1997; 56(3):287-294. 